\title{
SAND Mineralogy as a Criterion for Soil Uniformity North West Wadi El-Natrun
}

\author{
N.M. Bahnasawy \\ Desert Research Centre, Cairo, Egypt
}

\begin{abstract}
7 IVE soil profiles were selected to represent the two major soil 1 taxonomic subgroups (LCCM and LECN) NW Wadi ElNatrun. The sand subfraction $(0.125-0.063 \mathrm{~mm})$ of those soils were reseparated into light and heavy minerals (opaques and nonopaques).
\end{abstract}

The obtained results reveal that light minerals are mainly composed of quartz followed by low amounts of feldspars. Plagioclase and /or microcline predominates in both soils. Moreover, orthoclase is commonly the least abundant in the LCCM.

Regarding heavy minerals, opaques are the predominant content is. In both soil subgroups, opaques are dominated by oxides followed by sulphides while hydroxides are the least. In the non-opaques, amphiboles exceed pyroxenes, Parametamorphic, ubibutous, epidotes minerals in a descending order in the LCCM while the converse is true in the LECN.

The frequency and depthwise distributions of each identified mineral are presented for each profile and soil subgroups are interpreted in a trial to distinguish between those soil subgroups.

Based on the ratios between heavy minerals and weathering ratios, the soil origin, genesis and formation are predicted and graphical triangular presentation for opaque and non-opaque minerals suggested the possible use of pyroboles, epidote, and parametamorphic relation for soils differentia.

Keywords: Quartzpsamments, Torriorthents, Heavy and light minerals, Opaques, Non-opaques, Weathering ratios.

Wadi El Natrun is an elongate depression located in the north eastern part of the western desert, about $80 \mathrm{~km}$. North West of Cairo. It lies between longitudes $30^{\circ} \quad 10^{\prime}$ and $30^{\circ} 15^{`} \mathrm{~N}$ and latitudes $30^{\circ} 25^{\prime}$ and $30^{\circ} \quad 27^{`} \mathrm{E}$.The depression is about $50 \mathrm{~km}$. length, and has an average width of about $10 \mathrm{~km}$. The lowest point in the Wadi is about $23 \mathrm{~m}$ below sea level.

North-West of Wadi El-Natrun, elevated land (terraces) constitutes of mineral soils were formed. These soils were pedologically studied and classified according to Soil Taxonomy (2014) into two subgreat groups; Typic Quartzipsamments (LCCM) and Typic Torriorthents (LECN). Though the soils are of skeletal coarse nature, yet primary minerals are not given due 
consideration. Therefore, the present work was devoted to the mineralogy of sand fraction in a trial to implement some sand minerals in evaluating soil uniformity or discontinuity and development.

\section{Materials and Methods}

Nineteen soil samples were collected from eight soil profiles representing the two major soil subgroups identified in Wadi El Natrun (Fig. 1). The soil profiles were morphologically considered and the whole samples of all profiles were air - dried, ground with a wooden pestle in agate mortar, sieved through a $2 \mathrm{~mm}$ sieve and subjected to the following analyses:

-Particle size distribution by the dry sieving, (Retsch 2009).

-Calcium carbonate content was determined using Collin's calcimeter (Horvath et al., 2005).

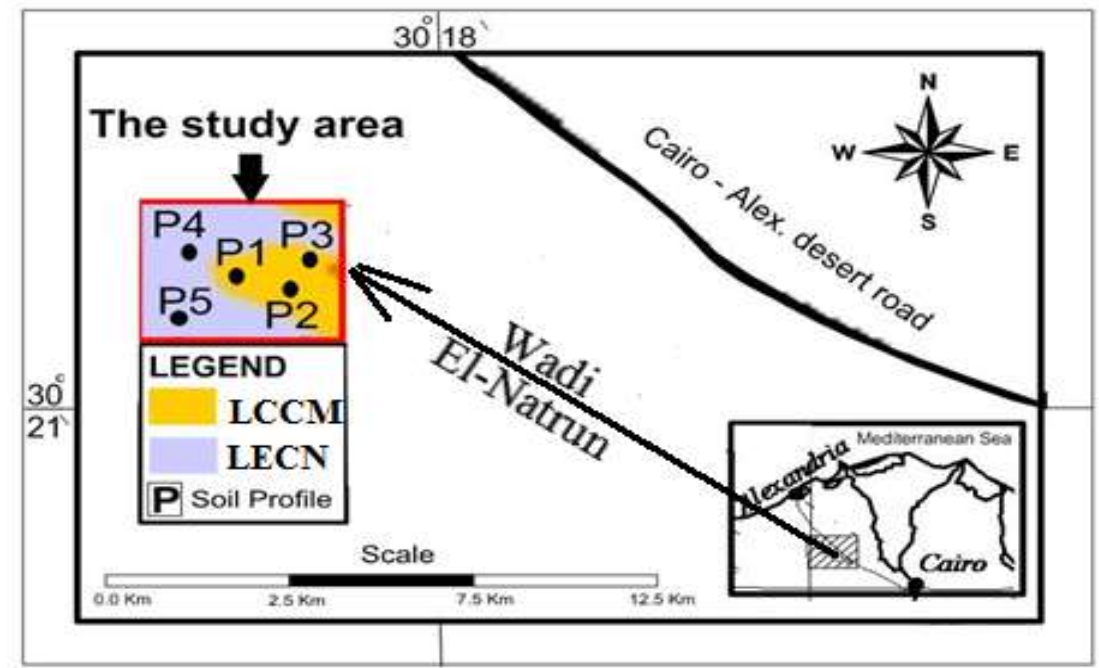

Fig. 1. Location of the studied soil profiles

Separation of sand fraction and pretreatments for sand mineralogy

The very fine sand fraction (0.063- $0.125 \mathrm{~mm}$ diameter) was separated from the soil samples by decantation and sieving through. After the essential pretreatments for removal of total carbonates and organic matter, Kettler et al. (2001), the separated sand fraction is further separated into heavy and light minerals using bromoform (SG $2.85 \pm 0.02$ ), (Biswas and Mukherjee 2006). The separated minerals were washed repeatedly with ethanol then mounted on glass slides using gum tragacanth and Canada balsam (RI 1.54), ( Karmakar 2014).

Egypt. J. Soil Sci. 56, No. 4 (2016) 


\section{Mineralogical identification of sand minerals}

Identification of the mounted sand minerals was carried out by the polarizing microscope with a graduated mechanical stage for traverse counts, Mange and (Maurer, 1992). The principles applied for identification through optical properties of minerals are those given by Jay (2015).

Approximately 500 grains in each slide were examined to minimize the absolute error, (Mahaney, 2002). Percentages of light and heavy minerals were counted without taking opaques, anhydrates and carbonates into account, (Cascalho et al., 2016).

Opaque minerals were investigated individually using the ore microscope (reflection system) following the mineral description given by Bowles et al. (2011).

\section{Results and Discussion}

Table 1 presents the distribution of sand fraction throughout the subsequent layers of the studied profiles representing the two major soil subgroups in NW Wadi El-Natrun area. To assess the mineral distribution properly, sand minerals were distinguished into two distinctive groups, i.e., light and heavy minerals, (Suresh and Raja, 2014). The latter group is further distinguished into opaques and non-opaques, and the individual members of both mineral groups are defined by their optical characteristics using polarized and ore microscopes for the former and latter groups, respectively, (John et al. 2015). An account on those mineral groups and their individual members in the studied profiles is given as follows.

\section{Light minerals}

These minerals are formed essentially of quartz, more than $91.0 \%$ of light minerals, with very low amounts of feldspars (Table 2).1-Quartz $\left(\mathrm{SiO}_{2}\right)$.

The colourless type of quartz is the predominant type in both Typic Quartzipsamments (LCCM) and Typic Torriorthents (LECN) soils of Wadi ElNatrun. Quartz constitutes 97.8 to $99.4 \%$ with a weighted mean of $98.3 \%$ of light minerals in the former soils while being 91.34 to $95.4 \%$ with a weighted mean of $93.3 \%$ of light minerals in the latter soils. In other words, the highest content is that of the Typic Quartzipsamments whereas Typic Torriorthents have relatively low quartz percent.

Depthwise distribution of quartz, (Fig. 2), reveals slight decrease of quartz in profiles 1 and 2 (LCCM) while other profiles related to both soil subgroups have an irregular pattern for quartz distribution downwards.

\section{Feldspars}

They are also detected in all the studied sand samples. They are composed essentially of three minerals namely; Orthoclase $\left(\mathrm{KAlSi}_{3} \mathrm{O}_{8}\right)$, 
TABLE 1. Calcium carbonate content and Particles size distribution in the studied soil profiles

\begin{tabular}{|c|c|c|c|c|c|c|c|c|c|c|}
\hline \multirow{3}{*}{$\begin{array}{c}\text { Taxonomic } \\
\text { soil subgroup }\end{array}$} & \multirow{3}{*}{$\begin{array}{c}\text { Profile } \\
\text { No. }\end{array}$} & \multirow{3}{*}{$\begin{array}{c}\text { Depth, } \\
\text { Cm. }\end{array}$} & \multirow{3}{*}{$\begin{array}{c}\mathrm{CaCO}_{3} \\
\%\end{array}$} & \multicolumn{6}{|c|}{ Particle size distribution $\%$} & \multirow{3}{*}{$\begin{array}{l}\text { Texture } \\
\text { Class }\end{array}$} \\
\hline & & & & \multicolumn{6}{|c|}{$(\mathrm{mm})$} & \\
\hline & & & & $2.0-1.0$ & $1.0-0.5$ & $0.5-0.25$ & $0.25-0.125$ & $0.125-0.063$ & $<0.063$ & \\
\hline \multirow{9}{*}{ LCCM } & \multirow{3}{*}{ (1) } & $0-25$ & 1.48 & 5.0 & 65.6 & 12.0 & 8.8 & 8.5 & 0.1 & Sand \\
\hline & & $25-60$ & 0.62 & 5.0 & 75.1 & 9.8 & 7.6 & 2.3 & 0.2 & Sand \\
\hline & & $60-140$ & 0.28 & 1.4 & 58.5 & 8.9 & 3.6 & 25.4 & 2.2 & Sand \\
\hline & \multirow{3}{*}{ (2) } & $0-40$ & 0.08 & 2.5 & 58.7 & 9.6 & 4.2 & 23.8 & 1.2 & Sand \\
\hline & & $40-70$ & 0.09 & 1.5 & 58.3 & 10.4 & 4.3 & 24.0 & 1.5 & Sand \\
\hline & & \begin{tabular}{|l|}
$70-130$ \\
\end{tabular} & 0.01 & 1.5 & 53.6 & 7.8 & 3.6 & 24.0 & 9.5 & Sand \\
\hline & \multirow{3}{*}{ (3) } & $0-40$ & 0.01 & 4.5 & 62.8 & 12.2 & 7.5 & 11.5 & 1.5 & Sand \\
\hline & & $40-70$ & 1.29 & 3.0 & 70.6 & 8.1 & 9.3 & 8.5 & 0.5 & Sand \\
\hline & & \begin{tabular}{|l|}
$70-150$ \\
\end{tabular} & 0.04 & 1.5 & 73.4 & 6.4 & 9.9 & 5.2 & 3.6 & Sand \\
\hline \multirow{10}{*}{ LECN } & \multirow{5}{*}{ (4) } & $0-25$ & 1.10 & 3.1 & 19.5 & 3.0 & 5.2 & 50.0 & 19.2 & Loamy sand \\
\hline & & $25-35$ & 0.40 & 1.7 & 55.8 & 6.9 & 2.9 & 15.6 & 17.1 & Loamy sand \\
\hline & & $35-60$ & 0.10 & 1.1 & 39.6 & 2.2 & 5.9 & 19.8 & 31.4 & Sandy loam \\
\hline & & $60-70$ & 0.30 & 1.2 & 2.3 & 0.3 & 0.2 & 60.5 & 35.5 & Sandy loam \\
\hline & & $70-90$ & 0.20 & 1.2 & 50.8 & 4.4 & 3.6 & 20.0 & 20.0 & Loamy sand \\
\hline & \multirow{5}{*}{ (5) } & $0-35$ & 1.19 & 1.8 & 4.6 & 0.4 & 0.3 & 62.4 & 30.5 & Sandy loam \\
\hline & & $35-55$ & 6.62 & 2.0 & 38.3 & 3.2 & 3.5 & 20.6 & 32.4 & Sandy loam \\
\hline & & $55-75$ & 0.01 & 3.5 & 32.4 & 3.4 & 2.8 & 24.4 & 33.5 & Sandy loam \\
\hline & & \begin{tabular}{|l|}
$75-110$ \\
\end{tabular} & 0.01 & 1.5 & 23.8 & 3.1 & 2.9 & 49.2 & 19.5 & Loamy sand \\
\hline & & $110-150$ & 0.01 & 0.5 & 42.3 & 5.7 & 3.3 & 26.8 & 21.4 & Loamy sand \\
\hline
\end{tabular}

Plagioclase (Na, Ca) ( $\mathrm{Si} A \mathrm{Al})_{4} \mathrm{O}_{8}$ and microcline ( $\mathrm{K}$ Al $\left.\mathrm{Si}_{3} \mathrm{O}_{8}\right)$. The orthoclase grains are colourless, partially cloudy with low relief, sometimes showing simple twinning. The plagioclase grains display a lamellar twinning, while microcline grains are characterized by the cross hatching twinning (polysynthetic quadraline structure). The frequency distribution of feldspars indicates that their content in the studied profiles varies widely between 0.60 and $8.66 \%$ of light minerals. The lowest content is found in the surface layer of profile 2 (LCCM), whereas the highest content is strictly confined to the top surface layer of profile 5 (LECN). In general, feldspars content is commonly higher in the latter soil subgroup. In other words, feldspars constitute 0.6 to 2.2 $\%$ and 4.60 to $8.66 \%$ of light minerals in the LCCM and LECN soil subgroups, respectively. Depthwise distribution of feldspars indicates a tendency of slight increase downward profiles 1 and 2 (LCCN) with an irregular distribution of feldspars in profile 3 of the same soil subgroup. On the other hand, the distribution pattern of feldspars dose not portray any specific pattern in the soils of profiles 4 and 5 representing Typic Torriorthents soils (LECN).

Further elucidation of the data, (Table 2), indicates that orthoclase is the predominant member of feldspars group in the studied soil profiles. Its content ranges from 0.11 to $0.80 \%$ with a mean of $0.32 \%$ and 0.94 to $2.96 \%$ with a mean of $2.02 \%$ of light minerals in the LCCM and LECN soil subgroups, respectively. Depthwise distribution of orthoclase does not follow any specific pattern pertaining to soil type (subgroup) nor to profile location. 
The second important mineral of feldspars group is plagioclase. It is detected in all the studied profiles and layers where it constitutes 0.28 to $0.96 \%$ with a weighted mean of $0.72 \%$ and 1.28 to $2.96 \%$ with a weighted mean of $2.36 \%$ in the LCCM and LECN soil subgroups, respectively.

TABLE 2. Frequency distribution of the light minerals $(0.125-0.063 \mathrm{~mm})$ in the sand fraction of Wadi El- Natrun soils

\begin{tabular}{|c|c|c|c|c|c|c|c|}
\hline \multirow{2}{*}{$\begin{array}{l}\text { Taxonomic soil } \\
\text { subgroup }\end{array}$} & \multirow{2}{*}{$\begin{array}{c}\text { Profile } \\
\text { No. }\end{array}$} & \multirow{2}{*}{$\begin{array}{l}\text { Depth, } \\
\text { Cm. }\end{array}$} & \multirow{2}{*}{$\underset{\%}{\text { Quartz }}$} & \multicolumn{3}{|c|}{ Feldspars \% } & \multirow{2}{*}{$\begin{array}{c}\text { Total } \\
\text { feldspars }\end{array}$} \\
\hline & & & & Orthoclase & Plagioclase & Microcline & \\
\hline \multirow{12}{*}{ LCCM } & \multirow{4}{*}{ (1) } & $0-25$ & 98.60 & 0.35 & 0.93 & 0.12 & 1.40 \\
\hline & & $25-60$ & 98.49 & 0.17 & 0.88 & 0.46 & 1.51 \\
\hline & & $60-140$ & 98.31 & 0.21 & 0.61 & 0.87 & 1.69 \\
\hline & & W. & 98.41 & 0.23 & 0.73 & 0.63 & 1.49 \\
\hline & \multirow{4}{*}{ (2) } & $0-40$ & 99.40 & 0.16 & 0.28 & 0.16 & 0.60 \\
\hline & & $40-70$ & 98.83 & 0.11 & 0.79 & 0.27 & 1.17 \\
\hline & & $70-130$ & 98.20 & 0.53 & 0.83 & 0.44 & 1.80 \\
\hline & & W & 98.70 & 0.32 & 0.65 & 0.76 & 1.29 \\
\hline & \multirow{4}{*}{ (3) } & $0-40$ & 98.00 & 0.80 & 0.35 & 0.85 & 2.00 \\
\hline & & $40-70$ & 98.40 & 0.18 & 0.82 & 0.60 & 1.60 \\
\hline & & $70-150$ & 97.80 & 0.29 & 0.96 & 0.95 & 2.20 \\
\hline & & $\mathrm{W}$. & 97.79 & 0.41 & 0.77 & 0.85 & 2.03 \\
\hline \multirow{12}{*}{ LECN } & \multirow{6}{*}{ (4) } & $0-25$ & 94.36 & 1.10 & 2.09 & 2.45 & 5.64 \\
\hline & & $25-35$ & 92.34 & 2.96 & 2.14 & 2.56 & 7.66 \\
\hline & & $35-60$ & 92.37 & 2.24 & 2.44 & 2.95 & 7.63 \\
\hline & & $60-70$ & 92.67 & 2.63 & 2.28 & 2.42 & 7.33 \\
\hline & & $70-90$ & 94.15 & 0.94 & 2.87 & 2.04 & 5.85 \\
\hline & & W. & 93.35 & 1.75 & 2.39 & 2.51 & 6.65 \\
\hline & \multirow{6}{*}{ (5) } & $0-35$ & 91.34 & 2.85 & 2.95 & 2.86 & 8.66 \\
\hline & & $35-55$ & 92.16 & 2.92 & 2.21 & 2.71 & 7.84 \\
\hline & & $55-75$ & 95.40 & 1.77 & 1.28 & 1.55 & 4.60 \\
\hline & & $75-110$ & 92.62 & 2.84 & 2.96 & 1.58 & 7.38 \\
\hline & & $110-150$ & 94.95 & 1.27 & 1.81 & 1.97 & 5.05 \\
\hline & & W. & 93.25 & 2.29 & 2.33 & 2.13 & 6.75 \\
\hline
\end{tabular}

W. : Weighted mean.

Depthwise distribution of plagioclase reveals three patterns; decrease with depth only in profile 1 , while increases with depth in profiles 2 and 3 of the LCCM and follows an irregular distribution pattern in both profiles of the LECN.

The least abundant mineral in the feldspars group is the microcline which constitutes $0.12-2.95 \%$ of the light minerals. The lowest content is detected in the top surface layer of profile 1 (LCCM) whereas the highest content is associated with the $(35-60 \mathrm{Cm}$.) of profile 4 (LECN). In general, the microcline content is considerably higher in soils of the LECN relative to LCCM. Depthwise distribution of microcline shows a tendency of increase downward in profiles 1 and 2 , while an irregular distribution pattern of microcline mineral of profile 3 (LCCM) and profiles 4 and 5 representing the soils of (LECN). 


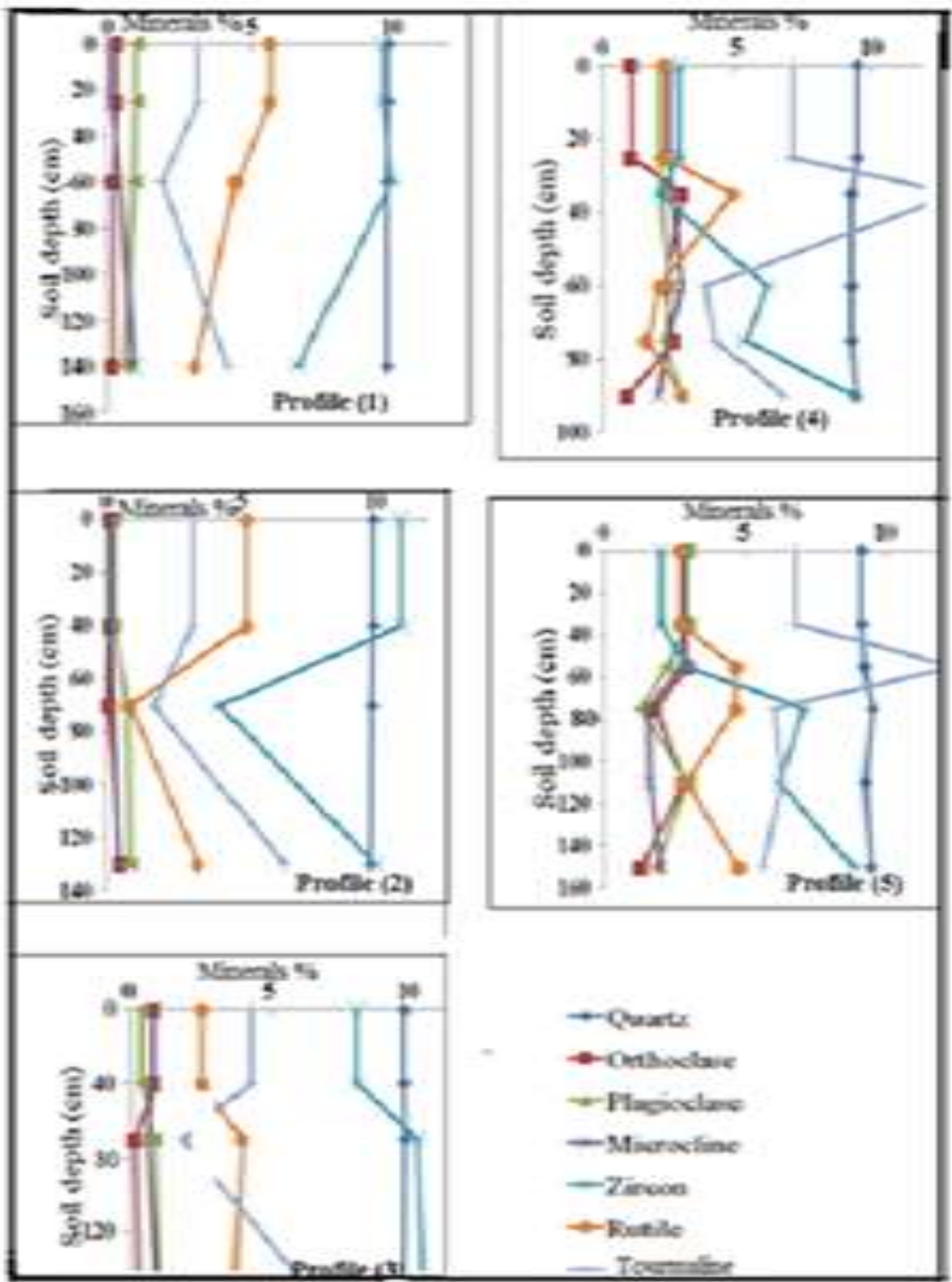

Fig. 2. Depthwise distribution of some heavy and light minerals in the soil subgroups (LCCM \& LECN) of the studied area

Heavy minerals:

Table 3 presents the content and distribution of heavy minerals identified in the sand fraction of the studied soil profiles. Since opaque minerals are the major constituents of heavy minerals they are given special consideration. Other heavy minerals (non-opaques) are also discussed.

\section{Opaques}

Opaque minerals content varies widely within and between the studied profiles. For instance, opaques content ranges from 65.8 to $75.5 \%$ and 47.8 to

Egypt. J. Soil Sci. 56, No. 4 (2016) 
$72.8 \%$ of heavy minerals in the soils subgroups of LCCM and LECN, respectively. Despite these wide variations in opaques \%, the weighted means of opaques in each soil subgroups are very close, being in the ranges of 70.3 to $72.3 \%$ and 58.2 to $60.8 \%$ in the LCCM and LECN soil subgroups, respectively. The nearly unique value of weighted mean suggests a unique origin of each soil subgroup and the variations encountered within each profiles are most probably rendered to opaques redistribution during sedimentation regime of parent sediments. This is clearly manifested on the vertical distribution of opaques which exhibits an irregular distribution throughout the entire depth of all investigated profiles except for profile 3 whose opaques content tends to increase with depth. It is also remarkable that the surface layer of all profiles has lower opaques content relative to the subsurface and deeper ones except for profiles 4 and 5 where the opaques percent depressed in the deepest layers.

To substantiate the individual members of opaques, ore microscope with a mechanical stage for traverse counts is used. Examination of opaques has distinguished three groups and their members as shown in Table 3. An account of these groups is presented as follows:

\section{Sulphides minerals group}

Data in Table 3 reveal the sulphides group constitutes 10.3 to $25.0 \%$ and 6.5 to $33.3 \%$ of total opaques in the LCCM and LECN soil subgroups, respectively. The lowest contents are detected in the deepest layer or closer (profiles 3 and 4) whereas the highest contents are those of the surface layer or closer (profiles 2 and 4). Depthwise distribution of sulphides group indicates a tendency of decrease downwards profiles 1 and 3 of the LCCM and an irregular pattern in other profiles. Is also remarkable that despite the apparent variations of sulphides within and between profiles, the weighted means of sulphides vary within a narrow limit (14.81 to $16.95 \%)$ in the LCCM while being almost equal in the LECN.

Proper examination of Sulphides minerals group has led to the identification of pyrite, chalcopyrite and Pyrthotite as follows:

i) Pyrite $\left(\mathrm{Fe} \mathrm{S}_{2}\right)$ is identified mostly in euhedral crystals with high relief, its colour in reflected light is brass yellow. It is detected in all samples as a major constituent of sulphide group where its content ranges from 6.6 to $18.8 \%$ and 3.9 to $22.1 \%$ of opaques in the LCCM and LECN soil subgroups, respectively. The vertical distribution of pyrite indicates a tendency of decrease downwards profile 3 (LCCM) and, to some extent, profile 5 (LECN). Other profiles exhibit an irregular pattern. It is also noticeable that higher pyrite content is associated with the uppermost soil surface or closer in both soil subgroups under study. 
TABLE 3. Frequency distribution of the main groups of opaque minerals and their individual members in the sand fraction of Wadi El- Natrun soils

\begin{tabular}{|c|c|c|c|c|c|c|c|c|c|c|c|c|c|}
\hline \multirow{3}{*}{ 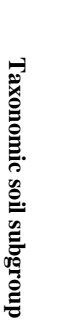 } & \multirow{3}{*}{ 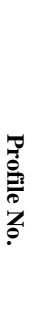 } & \multirow{3}{*}{ 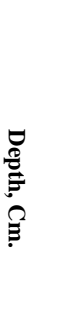 } & \multirow{3}{*}{ 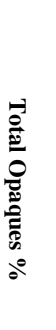 } & \multicolumn{10}{|c|}{ Opaque minerals groups \% } \\
\hline & & & & \multicolumn{4}{|c|}{ Sulphides } & \multicolumn{5}{|c|}{ Oxides } & \multirow{2}{*}{$\begin{array}{c}\begin{array}{c}\text { Hydro- } \\
\text { xides }\end{array} \\
\\
\\
\\
\\
\end{array}$} \\
\hline & & & & $\underset{ٍ}{\overparen{\sigma}}$ & 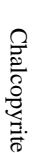 & 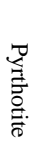 & $\begin{array}{l}\overrightarrow{0} \\
\stackrel{0}{E}\end{array}$ & 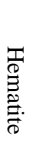 & 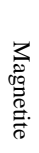 & 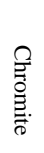 & 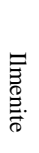 & $\begin{array}{l}\overrightarrow{0} \\
\stackrel{0}{\Xi}\end{array}$ & \\
\hline \multirow{12}{*}{ LCCM } & \multirow{4}{*}{ (1) } & $0-25$ & 66.3 & 14.7 & 6.2 & 1.7 & 22.6 & 0.6 & 46.1 & 15.1 & 2.2 & 64.0 & 13.4 \\
\hline & & $25-60$ & 73.8 & 18.2 & 2.3 & 2.0 & 22.5 & 1.0 & 42.8 & 15.6 & 3.4 & 62.8 & 14.7 \\
\hline & & $60-140$ & 71.7 & 8.9 & 1.7 & 0.9 & 11.5 & 0.9 & 50.2 & 17.7 & 3.8 & 72.6 & 15.9 \\
\hline & & w. & 72.3 & 12.3 & 2.7 & 1.3 & 16.3 & 0.9 & 47.6 & 16.7 & 3.4 & 68.6 & 15.2 \\
\hline & \multirow{4}{*}{ (2) } & $0-40$ & 67.8 & 16.8 & 7.5 & 0.7 & 25.0 & 0.8 & 30.2 & 21.0 & 9.8 & 61.8 & 13.2 \\
\hline & & $40-70$ & 75.5 & 7.9 & 3.3 & 0.9 & 12.1 & 1.9 & 48.0 & 19.9 & 3.7 & 69.8 & 14.4 \\
\hline & & $70-130$ & 72.1 & 12.0 & 1.2 & 0.8 & 14.0 & 1.6 & 59.5 & 10.2 & 4.4 & 75.7 & 10.3 \\
\hline & & w. & 71.6 & 12.5 & 3.6 & 0.8 & 16.9 & 1.4 & 47.8 & 15.8 & 5.9 & 70.9 & 12.1 \\
\hline & \multirow{4}{*}{ (3) } & $0-40$ & 65.8 & 18.8 & 4.8 & 0.9 & 24.5 & 1.0 & 36.7 & 15.3 & 2.7 & 55.7 & 19.8 \\
\hline & & $40-70$ & 70.3 & 7.2 & 6.1 & 0.6 & 13.9 & 1.4 & 40.0 & 25.9 & 5.3 & 72.6 & 13.5 \\
\hline & & $70-150$ & 72.6 & 6.6 & 2.8 & 0.9 & 10.3 & 0.9 & 57.3 & 17.2 & 4.5 & 79.9 & 9.8 \\
\hline & & w. & 70.3 & 10.0 & 4.0 & 0.8 & 14.8 & 1.0 & 48.4 & 18.4 & 4.2 & 72.0 & 13.2 \\
\hline \multirow{12}{*}{ LECN } & \multirow{6}{*}{ (4) } & $0-25$ & 59.7 & 12.0 & 6.6 & 4.1 & 22.7 & 1.6 & 36.7 & 25.0 & 8.3 & 71.6 & 5.7 \\
\hline & & $25-35$ & 71.5 & 22.1 & 7.5 & 3.7 & 33.3 & 1.5 & 22.9 & 25.9 & 5.6 & 55.9 & 10.8 \\
\hline & & $35-60$ & 70.0 & 6.9 & 1.8 & 1.0 & 9.7 & 1.3 & 30.8 & 32.0 & 7.0 & 71.1 & 19.2 \\
\hline & & $60-70$ & 47.8 & 3.9 & 1.7 & 0.9 & 6.5 & 0.9 & 60.4 & 14.3 & 3.1 & 78.7 & 14.8 \\
\hline & & $70-90$ & 51.9 & 7.0 & 1.0 & 1.1 & 9.1 & 0.9 & 63.1 & 11.6 & 5.1 & 80.7 & 10.2 \\
\hline & & w. & 60.8 & 9.7 & 3.5 & 2.2 & 15.4 & 1.3 & 42.0 & 22.9 & 6.4 & 72.6 & 12.0 \\
\hline & \multirow{6}{*}{ (5) } & $0-35$ & 56.9 & 18.2 & 8.1 & 4.0 & 30.3 & 1.0 & 20.2 & 31.7 & 6.6 & 59.5 & 10.2 \\
\hline & & $35-55$ & 72.8 & 10.9 & 7.3 & 3.7 & 21.9 & 1.3 & 40.7 & 21.9 & 8.0 & 71.9 & 6.2 \\
\hline & & $55-75$ & 71.5 & 7.0 & 1.9 & 1.0 & 9.9 & 2.0 & 32.3 & 29.5 & 7.5 & 71.3 & 18.8 \\
\hline & & $75-110$ & 52.1 & 4.7 & 1.7 & 0.9 & 7.3 & 0.8 & 54.6 & 20.5 & 2.7 & 78.6 & 14.1 \\
\hline & & $110-150$ & 50.7 & 7.6 & 0.9 & 0.8 & 9.3 & 0.9 & 62.9 & 13.8 & 3.4 & 81.0 & 9.7 \\
\hline & & w. & 58.2 & 9.8 & 3.8 & 3.3 & 16.9 & 1.1 & 44.0 & 22.7 & 5.1 & 72.9 & 10.9 \\
\hline
\end{tabular}

W.: Weighted mean.

ii) Chalcopyrite $\left(\mathrm{Cu} \mathrm{Fe} \mathrm{S}_{2}\right)$ is the second abundant mineral of sulphides group. The mineral content ranges from 1.2 to $7.5 \%$ and 0.9 to $8.1 \%$ of opaques in the LCCM and LECN soil subgroups, respectively.

Data also reveal that the mineral content varies from one profile layer to another and between profiles of the same soil subgroup as evidenced by weighted means. It is also clear that chalcopyrite content is higher in the top surface of profiles representing LCCM soils while being higher in the surface and subsurface layers of LECN soils and shows a tendency of decrease with depth in profiles 1 and 2 of the former soil subgroup, profile 5 and, to some extent, profile 4 of the latter subgroup but exhibits an irregular depthwise distribution in profile 3 .

Egypt. J. Soil Sci. 56, No. 4 (2016) 
iii) Pyrthotite $[(\mathrm{Fe}, \mathrm{Ni}, \mathrm{Co}) 1-x \mathrm{~S}$ where $x=0.0$ to 0.2$]$ grains are detected in various shapes with basal parting, the colour in reflected light is copper-red. The mineral is the least abundant in sulphide minerals group as it constitutes 0.6 to 2.0 and 0.8 to $4.1 \%$ of opaques in the LCCM and LECN soil subgroups, respectively. The variations in the minerals content within and between soil profiles representing both soil subgroups and the different values of weighed mean suggest that this mineral could not be used for soil differentia. Nevertheless, the vertical distribution of pyrthotite shows an irregular pattern and apparent tendency of decrease with depth in the LCCM and LECN soil subgroups, respectively. A remarkable feature is the increase of pyrthotite content in the subsurface layers of profiles representing LECN soil subgroup, while the apparent increase of the mineral is noticed in the subsurface of profiles 1 and 2 and in the surface of profile 3 (LCCM). It is also evident that a layer or more in most profiles attain nearly the same content of this mineral and this can be attributed to the genesis of sediments in such layers.

\section{Oxide minerals group}

This group of minerals is the abundant group of opaques in the studied soil subgroups where their content ranges from 55.7 to $79.9 \%$ and 55.9 to $81.0 \%$ of opaques in the LCCM and LECN soil subgroups, respectively. Within this group of minerals, hematite, magnetite, chromite and ilmenite are the members identified in the studied soil profiles.

Data in Table 3 show that the lowest contents in (LCCM) soils are found in the surface layer of profile 3.In the soils of (LCCM) the highest value is detected in the deepest layer of profile 3 while the highest contents are associated with the deepest layers of profiles 5 , whereas the lowest vales is found in the subsurface layer of profile 4. It is also clear that the weighted means of LECN soil subgroup are slightly higher than those of the LCCM.

The vertical distribution of oxide minerals shows two patterns of increasing oxide minerals with depth (profiles 2, 3 and 5) and irregular distribution in the other profiles regardless of soil subgroups.

To get more information about the distribution of oxide minerals, in the studied profiles, an account of the individual members of this group is given as follows:

i) Hematite $\left(\mathrm{Fe}_{2} \mathrm{O}_{3}\right)$ generally occurs in euhedral crystals, sometimes displays parting. It has a bloody red translucent edge and its colour in the reflected light is red. Table (3) shows that hematite content ranges from o.6 to 1.9 and 0.8 to $2.0 \%$ of opaques in the LCCM and LECN soil subgroups respectively. The lowest contents characterize the surface layer of profile1 and the $75-110 \mathrm{Cm}$. layer of profile 5 , while the highest hematite contents are associated with the subsurface layer of profile 2 and the $55-75 \mathrm{Cm}$. layer of profile 5. Though the weighted means of hematite are variable in each soil subgroup, yet relative increase of its content is remarkable in the subsurface layers of LCCM and in the uppermost surface layers of LECN soil subgroup. 
The vertical distribution of hematite shows a common irregular pattern except for profile 4 which exhibits a tendency of hematite decrease downwards, therefore the specific pattern pertaining to soil subgroup could not be recognized.

ii) Magnetite $\left(\mathrm{Fe}^{2+} \mathrm{Fe}^{3+}{ }_{2} \mathrm{O}_{3}\right)$ is identified as octahedral crystals with octahedral parting giving a steel block luster in the reflected light. The mineral is detected in all the studied profiles as a major constituent of the oxide minerals where its content varies from 30.2 to $59.5 \%$ and 20.2 to $63.1 \%$ of opaques in the LCCM and LECN soil subgroups, respectively. The lowest contents characterize the surface layers of profiles 2 (LCCM) and 5 (LECN) whereas the highest contents are strictly confined to the deepest layers of profiles 2 and 4 . It is also apparent that the weighted mean of magnetite is quite similar within each soil subgroup, suggesting unique origin with chance of variation within parent sediments followed by modification in magnetite contents in the subsequent profiles layers throughout sedimentation regime and prevailing environments. Depthwise distribution of magnetite shows a tendency of increase downwards profiles 2 and 3 of the LCCM soil subgroup with an irregular distribution pattern in the other profiles of both soil subgroups.

iii) Chromite $\left(\mathrm{Fe} \mathrm{Cr}_{2} \mathrm{O}_{4}\right)$ is the second abundant mineral of oxides group. It is identified by the minute octahedral crystals with translucent and brown thin edges and its luster is brownish black in the reflected light. Chromite is present in all the examined samples irrespective of location of soil subgroups. It constitutes 10.2 to $25.9 \%$ and 11.6 to $32.0 \%$ of opaques in the studied profiles representing LCCM and LECN soil subgroups. Therefore, its content is seemingly higher in the latter soil subgroup relative to the former one. The mineral distribution varies from one layer to another within each profile and also from one profile to another within each soil subgroup, this is reflected on the weighted mean of chromite in the different profiles of each soil subgroup and the vertical distribution of chromite in these profiles where chromite tends to increase with depth in profile 1 in contrast to profile 2 while follows an irregular pattern in the rest of profiles of both soil subgroups.

iv) Ilmenite $\left(\mathrm{Fe}^{2+} \mathrm{Ti}_{3}\right)$ is the third abundant mineral of the oxides group. It is distinguished by its violet black luster in the reflected light and some of its crystals displayed basal parting. Ilmenite content varies from 2.2 to $9.8 \%$ and 2.7 to $8.3 \%$ of opaques in the LCCM and LECN soil subgroups, respectively. The variations in ilmenite content within the subsequent layers of each profile and from one profile to another within each soil group and between soil subgroups are reflected on the depthwise distribution and weighted mean of ilmenite. Nevertheless, the weighted means of ilmenite suggest that this mineral can distinguish between the concerned soil subgroups as the weighted mean of ilmenite is considerably higher in LECN relative to the LCCM soil subgroup. 


\section{Hydroxides minerals group:}

- Limonite $\left[\mathrm{Fe} \mathrm{O}(\mathrm{OH}) . \mathrm{nH}_{2} \mathrm{O}\right]$ is the only identified mineral in this group. Limonite crystals show isotropism between cross nichols, and a yellowish brown luster in the reflected light. Limonite content varies within and between the studied profiles where it constitutes 9.8 to $19.8 \%$ and 5.7 to $19.2 \%$ of opaques in the LCCM and LECN soil subgroups, respectively. Computation of the weighted mean of limonite reveals that its content is somewhat higher in the LCCM soil subgroup relative to the LECN one, suggesting that limonite could be used to differentiate the soil subgroups under study. The vertical distribution of limonite shows three patterns in the LCCM soil subgroup where limonite tends to increase downward profile 1 while decreases with depth in profile 3 and has irregular pattern in profile 2 like the profiles of LECN subgroup.

\section{Relationship between the individual groups of opaques.}

In a trial to find out a relationship, if any, to distinguish the soil subgroups under study, a triangular presentation of the individual groups of opaques was conducted. The obtained triangle (Fig.3) dictates that the triangle failed to reach a reliable distinction between the concerned soil group.

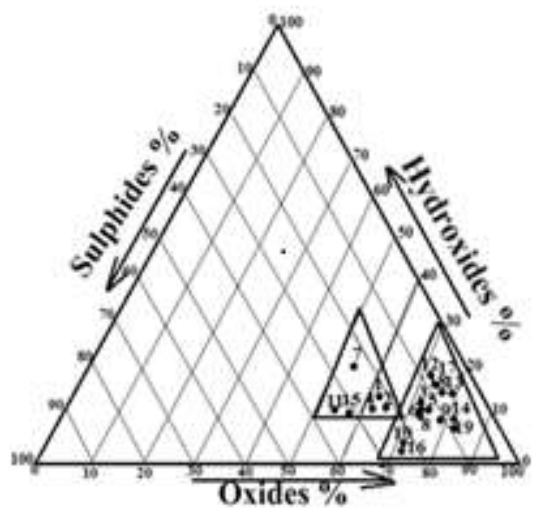

\section{Fig.(3):Triangular representation of hydroxides \& sulphides \& oxides relationship in the studied soils.}

\section{Non-opaque minerals}

Table 4 shows that augite, hornblende, epidote, andalusite and Kyanite are the most abundant minerals in the non-opaque fraction of the studied soils. Dioposide, tremolite, glaucophane, zoisite, clinozoisite, garnet, staurolite, zircon, rutile, tourmaline and biotite are present in subordinate amounts while other identified minerals are found in traceable amounts. It is also clear that the minerals of the Parametamorphic and pyroboles groups are the most abundant. An account on the identified minerals groups is given hereafter. 


\section{Pyroxenes}

Minerals of this group are detected in all layers of the studied profiles. They are found in subangular or subrounded grains having the greenish yellow, brownish and colourless varieties. Augite is the most common and abundant member in this group. It occurs in short prismatic crystals, mostly colourless to pale brown, sometimes pale green. Some crystals show polysynthetic twinning with wavy extinction.

1- Augite $\left[(\mathrm{Ca}, \mathrm{Na})(\mathrm{Mg}, \mathrm{Fe}, \mathrm{Al})(\mathrm{Al}, \mathrm{Si})_{2} \mathrm{O}_{6}\right]$ content ranges from 7.8 to 16.5 and 15.3 to $36.0 \%$ in LCCM and LECN soil subgroups, respectively, i. e, augite content is considerably high (about 2 folds) in

the LECN soil subgroup relative to LCCM. Computation of the weighted mean of augite reveals that LCCM soil profiles have a lower mean while LECN soils have the highest mean, about 2 folds that of TQz soil.

2- Diopside $\left(\mathrm{Ca} \mathrm{Mg} \mathrm{Si}_{2} \mathrm{O}_{6}\right)$ crystals are identified by its pale green colour and fairly high relief, with strong birefringence. The mineral constitutes 0.1 to $5.0 \%$ of the non-opaques.

As to the vertical distribution of augite, data show that its content in LCCM displayed a tends to decrease in profiles 1 and 2 while tends to decrease with depth in profile 3 and decrease downwards then increased abruptly in the deepest layers of both profiles of LCCM.

3- Hyperthene $\left(\mathrm{Sb}_{2} \mathrm{O}_{2}\right)$ is distinguished from augite by the inclusions (Schiller structure) having pale green colour. Its content is somewhat higher in LECN soil relative to the LCCM; this is rendered to its absence in many layers of profiles representing LCCM while being absent only in one layer of LECN. Also, its content expressed in weighted mean is 0.1 to 0.4 and 0.1 to $5.7 \%$ of non-opaques of LCCM and LECN, respectively, confirming the relative abundance in TT soil subgroup.

4- Likewise, Enstatite $\left(\mathrm{Mg}_{2} \mathrm{Si}_{2} \mathrm{O}_{6}\right)$ which is identified by prismatic colourless crystals with Schiller structure inclusions, weak birefringence and the interference colour is pale yellow of the first order, is absent in many layers of the LCCM profiles. Its content does not exceed $0.2 \%$ in the LCCM while reaches up to $3.6 \%$ of non-opaques in the LECN soils.

\section{Amphiboles}

This mineral group constitutes 13.6 to $21.2 \%$ and 13.6 to $26.1 \%$ of the nonopaques in LCCM and LECN soil subgroups, respectively, i.e., have somewhat higher content in LECN relative to LCCM. The main identified mineral of this group is hornblende, followed by glaucophane and tremolite which are also higher in the LECN relative to LCCM.

1-Hornblende $\left(\mathrm{Ca}_{2}\left(\mathrm{Mg}, \mathrm{Fe}^{2+}, \mathrm{Fe}^{3+}, \mathrm{Al}\right)_{5}(\mathrm{Si}, \mathrm{Al})_{8} \mathrm{O}_{22}(\mathrm{OH})_{2}\right.$ is found as subangular prismatic crystal in two varieties dominated by light green with very

Egypt. J. Soil Sci. 56, No. 4 (2016) 
few of the brown type, it is also characterized by a strong pleochrism. The hornblende content varies from 6.9 to $15.6 \%$ and 1.7 to $11.9 \%$ of the nonopaques in LCCM and LECN soil subgroups, respectively, indicating its abundance in the LCCM rather than LECN. This is also clarified by the weighted mean of hornblende in LCCM which is about 2 folds that of LECN. The frequency distribution of hornblende shows variations within and between profiles representing both soil subgroups. Also, depthwise distribution reveals a tendency of hornblende decrease with depth in profile 3 (LCCM) while other profiles of both subgroups exhibit an irregular distribution pattern.

Other identified minerals in the amphiboles group are:

2-Tremolite $\left(\mathrm{Ca}_{2}(\mathrm{Mg}, \mathrm{Fe})_{5} \mathrm{Si}_{8} \mathrm{O}_{22}(\mathrm{OH})_{2}\right.$ and 3-Glaucophane $\left(\mathrm{Na}_{2} \mathrm{Mg}_{3} \mathrm{Al}_{2}\right.$ $\mathrm{Si}_{8} \mathrm{O}_{22}(\mathrm{OH})_{2}$ which occur in subordinate amounts, not exceeding 4.4 and $8.5 \%$ of the non-opaques in the studied soils subgroups. Those minerals have relative abundance in the LECN soil relative to LCCM soil as revealed from their weighted means in profiles representing each soil subgroup.

\section{Epidotes minerals}

Among this group epidote is the most abundant mineral while zoisite and clinozoisite are detected in subordinates amounts. This mineral group constitutes 7.4 to $12.3 \%$ and 8.7 to $22.9 \%$ of the non-opaques in the LCCM and LECN soil subgroups; i.e., its content is considerably higher in the LECN relative to LCCM.

1-Epidote $\left(\mathrm{Ca}_{2}\left(\mathrm{Fe}^{3+}, \mathrm{Al}\right)_{3}(\mathrm{SiO} 4)_{3}(\mathrm{OH})\right.$ mineral forms 3.8 to $10.0 \%$ and 4.3 to $15.9 \%$ of the non- opaques in the LCCM and LECN soil profiles, respectively. The epidote content is therefore relatively high in the LECN than in LCCM as verified by weighted means of profiles representing both soil subgroups. Epidote is identified by the granular to columnar crystals with yellowish green colour rarely colourless, high relief and moderate to strong birefringence. The frequency distribution of this mineral varies from one profile to another and also within profiles as revealed by the depthwise distribution which revealed a tendency of increase downwards profiles 2 and 3 (LCCM) with an irregular distribution in the rest of soil profiles.

As previously mentioned 2- Zoisite $\left(\mathrm{Ca}_{2} \mathrm{Al}_{3}\left(\mathrm{SiO}_{4}\right)_{3}(\mathrm{OH})\right.$ and 3-Clinozoisite $\left(\mathrm{Ca}_{2} \mathrm{Al}_{3}\left(\mathrm{SiO}_{4}\right)_{3} \mathrm{OH}\right)$ are found in subordinate amounts but relatively higher content of clinozoisite occurs in LECN soil relative to LCCM one. Their frequency and depthwise distributions do not portray any specific pattern pertaining to the soil subgroups under study.

Parametamorphic minerals group

The main members of this group are dominated by andalusite followed by kyanite, garnet, staurolite while sillimanite is found in traceable amounts not exceeding $6.1 \%$ of the non-opaques in the studied soils. 


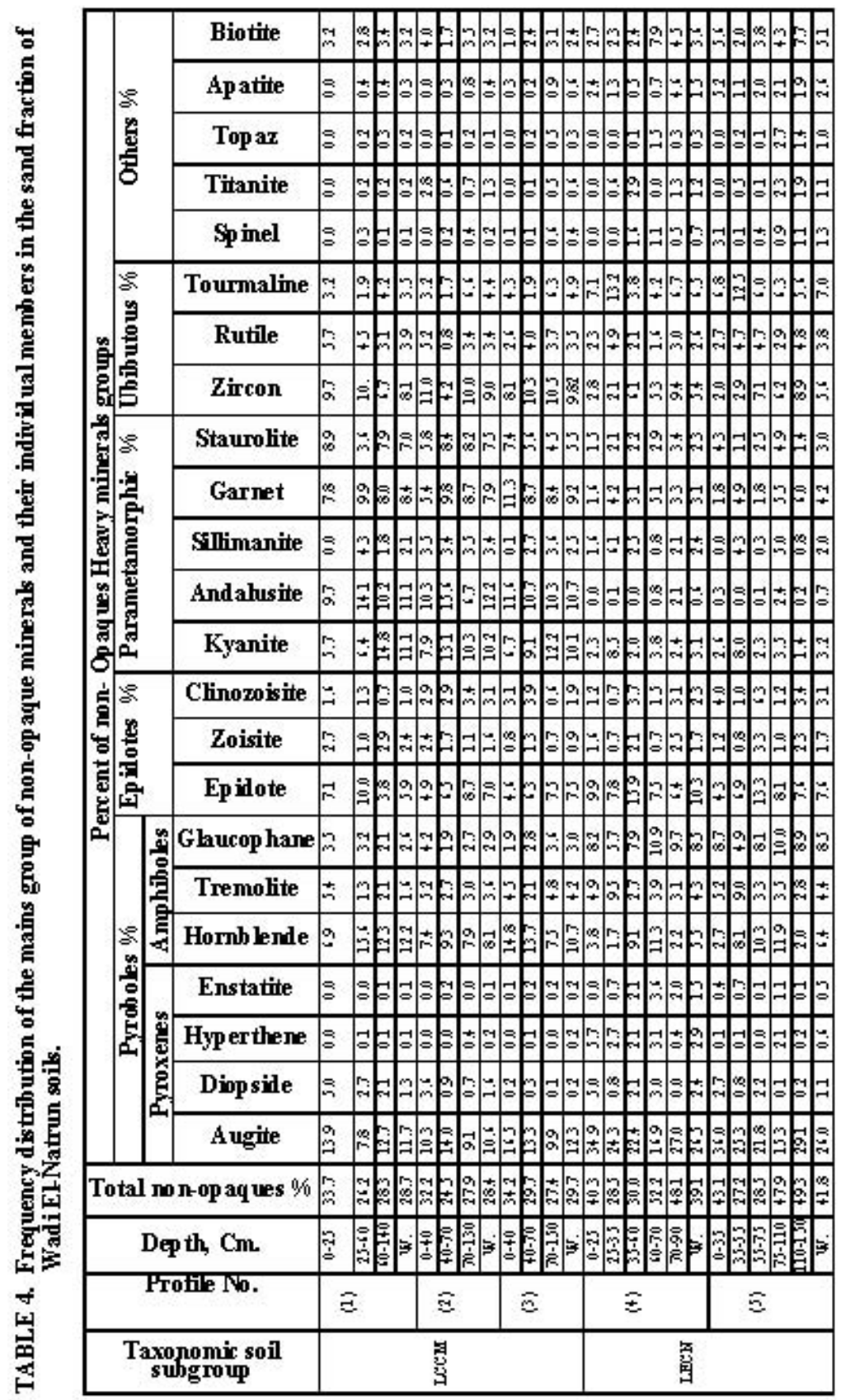


1-Kyanite $\left(\mathrm{Al}_{2} \mathrm{SiO}_{5}\right)$ is identified by its colourless elongated platey crystals with two perfect cleavage sets at angles around $8.7^{\circ}$. It constitutes 5.7 to $14.8 \%$ and 1.4 to $8.5 \%$ in the LCCM and LECN soil subgroups, respectively. In other words, kyanite content is markedly higher in the LCCM if compared with LECN soil. This is verified by the computed weighted means of kyanite in the studied soil profiles. Frequency distribution of kyanite content varies from one profile to another and even within profiles layers as shown by its depthwise distribution which shows two distinct patterns, a tendency of increase downwards profiles 1 and 3 (LCCM) and an irregular pattern in the rest profiles, but still no specific pattern could distinguish certain soil subgroups from the other.

2-Andalusite $\left(\mathrm{Al}_{2} \mathrm{SiO}_{5}\right)$ is among the major minerals of the Parametamorphic group in the LCCM soil subgroup where its content varies from 6.7 to $15.6 \%$ of the non-opaques while being of very low content $(0.0-2.4 \%)$ in the LECN soil subgroup and its absence in some layers of the representative soil profiles is remarkable. The mineral is identified by its euhedral crystals (orthorhombic) or columnar aggregates having nearly square cross sections, fibrous compact to massive, colourless to pink or green, vitreous luster, double refractive, strongly trichroic pleochrism and transparent to nearly opaque with inclusions. The frequency distribution of andalusite shows significant abundance in the LCCM and its vertical distribution in both soil subgroups is irregular except in profiles where the mineral showed a slight decrease downwards.

3-Sillimanite $\left(\mathrm{Al}_{2} \mathrm{SiO}_{5}\right)$ is identified by its colourless prismatic crystals forming fibrous mass. It is detected in all layers of the studied profiles in low amounts except the surface layers of profiles 1 (LCCM) and 5 (LECN). Its content varies within and between profiles, being from 0.0 to $4.3 \%$ and $0.0-6.1$ $\%$ of the non-opaques of the LCCM and LECN soil subgroups, respectively. Its vertical distribution is irregular in all profiles except profile 3 where sillimanite tends to increase with depth and the variations in profiles weighted mean are quite noticeable.

4- Garnet $\left(\mathrm{A}_{3} \mathrm{~B}_{2} \mathrm{Si}_{3} \mathrm{O}_{12}\right.$ where $\mathrm{A}$ is a divalent cation $\left(\mathrm{Fe}^{2+}, \mathrm{Ca}^{2+} \mathrm{Mg}^{2+}\right)$ and $\mathrm{B}$ ... etc. and 5- Staurolite $\left(\mathrm{Fe}^{2+}, \mathrm{Mg}\right)_{2} \mathrm{Al}_{9}\left(\mathrm{Si}, \mathrm{Al}_{4} \mathrm{O}_{20}(\mathrm{O}, \mathrm{OH})_{4}\right.$ are also among the abundant minerals in the LCCM soil subgroup. The former is identified its colourless, sometimes pale reddish colour, euhedral crystals in six-sided to eight- sided sections having very high relief, and shows isotropy under cross nicols. The latter mineral is characterized by its subangular grains, sometimes prismatic, having strong pleochrism, and almost stained with inclusions. Both minerals are detected in all profiles layers representing both soil subgroups. Their content ranges from 5.4 to $11.3 \%$ and 1.6 to $6.0 \%$ and from 3.6 to 8.9 and 1.1 to $4.9 \%$ of the non-opaques for garnet and staurolite in the LCCM and LECN soil subgroups, respectively. Their distribution varies from one profile to another as indicated by the weighted means of each profile. Moreover, the vertical distribution of both minerals is irregular in all profiles except in profile 3 where their contents tend to decrease downward.

Egypt. J. Soil Sci.56, No. 4 (2016) 


\section{Ubibutous minerals group}

This minerals group includes the most stable and highly resistant minerals to weathering in soils. The main members of this group are zircon, rutile and tourmaline which constitute, on weighted mean basis, 8.97, 3.6 and $4.3 \%$ and $5.5,3.2$ and $6.8 \%$ of the non-opaques of the LCCM and LECN soil subgroups, respectively. This means that zircon is the most abundant followed by tourmaline and rutile within this minerals group in the LCCM soil while tourmaline is the abundant followed by zircon and rutile in the LECN soil. An account on each of these minerals is given hereafter.

1-Zircon $\left(\mathrm{Zr}\left(\mathrm{SiO}_{4}\right)\right.$ is recognized by its colourless short prismatic crystals with very high relief and the surface of some grains is stained with inclusions. Its content ranges from 4.2 to 11.0 and 2.1 to $9.4 \%$ of the non-opaques in the LCCM and LECN soil subgroups, respectively, indicating more abundance in the former soil subgroup. This is further confirmed by zircon weighted means of the studied soil profiles which range from 8.10 to $9.82 \%$ of non-opaques in the LCCM while being around $5.5 \%$ of the non-opaques in the LECN soil. The vertical distribution of $\mathrm{Zr}$ follows an irregular pattern in all soil profiles except for profile 3 (LCCM) where $\mathrm{Zr}$ tends to increase with soil depth.

2-Rutile ( $\mathrm{TiO} 2)$ is the least abundant mineral among the Ubibutous group. It is recognized by its rounded or subangular elongated grains with high relief and bloody red colour. The mineral constitutes 0.8 to 5.7 and 1.6 to $4.9 \%$ of the non-opaques in the LCCM and LECN soil subgroups, respectively. The frequency distribution is variable within and between soil profiles representing both soil subgroups, this is clearly evidenced from the weighted mean of soil profiles and each soil subgroups. This is also clearly evident from the vertical distribution of rutile which exhibits an irregular pattern in all profiles except for profile 1 where rutile tends to decrease gradually with depth.

3-Tourmaline $\left[\mathrm{R}_{9} \mathrm{Al}_{3}(\mathrm{~B}-\mathrm{OH}-\mathrm{F})_{2} \mathrm{Si}_{4} \mathrm{O}_{19}\right]$. Where $\mathrm{R}$ is a combination of: $(\mathrm{H}$, $\mathrm{Al}, \mathrm{Mg}, \mathrm{Fe}, \mathrm{Al}, \mathrm{Cr}, \mathrm{Fe}, \mathrm{K}$ and $\mathrm{Na}$ ) is recognized by its prismatic and rounded grains, colourless to pale yellow and sometimes natural grey, with strong pleochrism. Its content varies widely from 1.7 to 6.6 and 4.2 to $13.2 \%$ of nonopaques in the LCCM and LECN soil subgroups, respectively. The weighted means of the mineral in the studied soil profiles dictate the abundance of tourmaline in the LECN relative to LCCM soil. Obviously, the frequency and depthwise distribution indicate variability in tourmaline contents within and between soil profiles under study.

\section{Other identified minerals}

Spinel $\left(\mathrm{MgAl}_{2} \mathrm{O}_{4}\right)$, titanite $\left(\mathrm{Ca} \mathrm{Ti}\left(\mathrm{SiO}_{4}\right) \mathrm{O}\right)$, topaz $\left(\mathrm{Al}_{2} \mathrm{SiO}_{4}(\mathrm{~F}, \mathrm{OH})_{2}\right)$ and apatite $\left(\mathrm{Ca}_{5}\left(\mathrm{PO}_{4}\right)_{3}(\mathrm{OH}, \mathrm{F}, \mathrm{Cl})\right.$ are detected in minute amounts and sometimes absent especially in the top layers of soil profiles irrespective of soil their subgroups. These minerals were identified according to their optical profiles, Jay (2015), and their distribution is recorded (Table 4). Among the other minerals, biotite $\left[\mathrm{K}\left(\mathrm{Mg}, \mathrm{Fe}^{2+}{ }_{3}\right)\left(\mathrm{Al}, \mathrm{Fe}^{+}\right) \mathrm{Si}_{3} \mathrm{O}_{10}(\mathrm{OH}, \mathrm{F})_{2}\right]$ is identified by its tabular euhedral crystals, strong pleochrism, and strong absorption when cleavage traces are parallel to vibration plane of the lower nichol. Its content Egypt. J. Soil Sci. 56, No. 4 (2016) 
ranges from 1.0 to $4.0 \%$ and 2.0 to $7.9 \%$ of non-opaques in the LCCM and LECN soils, respectively, indicating pronounced abundance in the LECN soil relative the LECN one. The weighted means of biotite verified such abundance. The mineral displayed an irregular distribution pattern either within or between profiles representing both soil subgroups except for profile 3 (LCCM) where biotite tends to increase downwards.

\section{Weathering ratios}

Computation of the stable minerals ratios and weathering ratios for the studied soil profiles representing the LCCM and LECN soil subgroups, Table (5), reveals that the stable (highly resistant) minerals ratios displayed a pronounced increase in the LCCM soil relative to the LECN soil. For convenience, the ratios are in the ranges of 1.7- 5.25, 1.60-5.42 and 0.92- 1.75 for $\mathrm{Z} / \mathrm{R}, \mathrm{Z} / \mathrm{T}$ and $\mathrm{Z} / \mathrm{R}+\mathrm{T}$ in the LCCM soil while, being $0.43-3.31,0.23-1.61$ and $0.12-1.03$ in the LECN soil. Therefore, these ratios could be used to distinguish soil of both subgroups. Nevertheless, the depthwise distribution of these ratios follows an irregular pattern in all profiles except for the $\mathrm{Z} / \mathrm{T}$ ratio in profile 2 (LCCM) where this ratio tends to decrease with depth. These distribution patterns throughout the entire depth of soil profiles are mostly rendered to the heterogeneous parent sediments and /or multi-depositional regime which resulted in the discontinuity of profiles layers irrespective of soil subgroup, profiles locality and soils environment. Needless to mention that variations in these ratios are mainly ascribed to the pre- wet climatic conditions rather than soil development under the prevailing arid to semi-arid climate.

TABLE 5. Minerals and weathering ratios as calculated from the heavy minerals

\begin{tabular}{|c|c|c|c|c|c|c|c|c|c|}
\hline \multirow{2}{*}{\begin{tabular}{|c|} 
Taxonomic \\
soil subgroup
\end{tabular}} & \multirow{2}{*}{$\begin{array}{c}\text { Profile } \\
\text { No. }\end{array}$} & \multirow[b]{2}{*}{ Depth, Cm. } & \multicolumn{3}{|c|}{ Stable minerals ratios* } & \multicolumn{3}{|c|}{ Weathering ratios* } & \multirow{2}{*}{$\begin{array}{l}\text { Index } \\
\text { figure }\end{array}$} \\
\hline & & & $\mathbf{Z} / \mathbf{R}$ & $\mathrm{Z} / \mathbf{T}$ & $\mathrm{Z} / \mathbf{R}+\mathbf{T}$ & $\mathbf{W r} \mathbf{r}_{1}$ & $\mathrm{Wr}_{2}$ & $\mathrm{Wr}_{3}$ & \\
\hline \multirow{9}{*}{ LCCM } & \multirow{3}{*}{ (1) } & $0-25$ & 1.70 & 3.00 & 1.10 & 2.69 & 0.53 & 0.25 & 2.0 \\
\hline & & $25-60$ & 2.22 & 5.30 & 1.60 & 2.58 & 1.31 & 0.24 & 2.8 \\
\hline & & $60-140$ & 2.20 & 1.60 & 0.92 & 2.89 & 1.13 & 0.31 & 2.5 \\
\hline & \multirow{3}{*}{ (2) } & $0-40$ & 2.12 & 3.44 & 1.31 & 2.16 & 0.52 & 0.28 & 2.1 \\
\hline & & $40-70$ & 5.25 & 2.47 & 1.68 & 4.92 & 1.58 & 0.29 & 3.1 \\
\hline & & $70-130$ & 2.94 & 1.52 & 1.00 & 1.43 & 0.48 & 0.21 & 2.6 \\
\hline & \multirow{3}{*}{ (3) } & $0-40$ & 3.12 & 1.90 & 1.17 & 3.06 & 1.19 & 0.08 & 1.9 \\
\hline & & $40-70$ & 2.58 & 5.42 & 1.75 & 2.66 & 1.12 & 0.19 & 2.4 \\
\hline & & $70-150$ & 2.84 & 1.67 & 1.05 & 1.55 & 0.45 & 0.18 & 2.6 \\
\hline \multirow{10}{*}{ LECN } & \multirow{5}{*}{ (4) } & $0-25$ & 1.22 & 0.39 & 0.30 & 6.31 & 0.38 & 0.27 & 1.5 \\
\hline & & $25-35$ & 0.43 & 0.16 & 0.12 & 2.97 & 0.11 & 0.15 & 2.5 \\
\hline & & $35-60$ & 2.90 & 1.61 & 1.03 & 4.89 & 0.92 & 0.24 & 2.3 \\
\hline & & $60-70$ & 3.31 & 1.26 & 0.91 & 5.55 & 1.19 & 0.83 & 0.9 \\
\hline & & $70-90$ & 3.13 & 1.40 & 0.97 & 2.76 & 0.14 & 0.28 & 1.1 \\
\hline & \multirow{5}{*}{ (5) } & $0-35$ & 0.74 & 0.29 & 0.21 & 6.34 & 0.31 & 0.64 & 1.3 \\
\hline & & $35-55$ & 0.62 & 0.23 & 0.17 & 3.18 & 0.53 & 0.13 & 2.7 \\
\hline & & $55-75$ & 1.51 & 1.18 & 0.66 & 3.50 & 0.79 & 0.29 & 2.5 \\
\hline & & $75-110$ & 2.14 & 0.98 & 0.67 & 3.52 & 0.95 & 0.34 & 1.1 \\
\hline & & $110-150$ & 1.85 & 1.59 & 0.86 & 2.99 & 0.14 & 0.53 & 1.0 \\
\hline
\end{tabular}

Notes: Z. $=$ Zircon. R. $=$ Rutile. $\mathrm{T}$. $=$ Tourmaline, $\mathrm{Wr}_{1}=$ Pyroxenes + Amphiboles/Zircon +Tourmaline. $\mathrm{Wr}_{2}=$ Hornblende/Zircon + Tourmaline and $\mathrm{Wr}_{3}=$ Biotite/Zircon+ Tourmaline. 
Considering the weathering ratios, data reveal that $\mathrm{Wr}_{\mathrm{i}}$ ratio has higher values (2.76-6.34) in the LECN soil relative to the LCCM soil (3.06-4.92). Likewise, $\mathrm{Wr}_{3}$ ratios follows nearly the same pattern but with lower magnitude. On the contrary, $\mathrm{Wr}_{2}$ ratio is quite higher for LCCM soil (0.45-1.58) relative to LECN soil (0.11-1.19). Moreover, all weathering ratios exhibit an irregular patterns throughout the entire depth of all profiles representing both soil subgroups except for $\mathrm{Wr}_{1}$ and $\mathrm{Wr}_{2}$ ratios of profile 3 (LCCM) where those ratios tend to decrease with depth, this may be due to the weather ability of pyroboles, particularly hornblende, provided that their parent materials are homogenous. The higher ratios of $\mathrm{Wr}_{1}$ are expected since pyroboles constitute, 43.3-55.8\% and $23.8-38.0 \%$ of heavy minerals in the LECN and LCCM soil subgroups, respectively, meanwhile the $\mathrm{Z}+\mathrm{T}$ weighted means are somewhat lower in LECN relative to LCCM, thus the ratios are higher for LECN. This does not preclude the possible weathering of pyroboles but in a lower magnitude under the prevailing soil environments.

On the contrary, the relatively low contents of hornblende (6.9-15.6 and 1.7$11.9 \%$ in the LCCM and LECN soils) and the low content of biotite (1.0-4.0 and 2.0-7.9 \% of non-0paques of LCCM and LECN) are reflected on the small ratios of $\mathrm{Wr}_{2}$ and $\mathrm{Wr}_{3}$.

In short, the higher values of $\mathrm{Wr}_{1}$ ratio indicate that pyroboles (pyroxenes + amphiboles) which are susceptible to weathering predominates, thus dictate that the studied soils are young and less developed from the pedological view point. If all weathering ratios are considered jointly, one can conclude that the studied soil subgroups are young and immature (none to slightly developed) since the soil forming factors are not sufficient to complete soil development under the prevailed aridity. Again, this supports the belief that most variations in the studied minerals contents are mainly due to the chance of variation within the parent rock from which these soil subgroups are derived with a pronounced contribution of sedimentation regime and this is surely reflected on the weathering ratios which clarified apparent discontinuity and probably minute soil Heavy minerals relationships development confronted by prevailing aridity.

A trial is made to distinguish the soil subgroups under study where, four triangular representations are worked out (Figs. (4-7). From these figures, it is quite evident that the triangle of pyroboles, epidote and parametamorphic minerals has sufficiently differentiated both soil subgroups, followed by amphiboles, pyroxenes and ubibutous triangle which is somewhat efficient. Other triangular representations either of opaque minerals or non-opaques failed to distinguish between both soil subgroups under study.

Based on the foregoing, the author recommends the use of the former two relationships for soils differentia. This is clearly remarkable since there is a definite and distinct 3 one zone occupied by each soil subgroup formed of particular type of sediments.

Egypt. J. Soil Sci. 56, No. 4 (2016) 


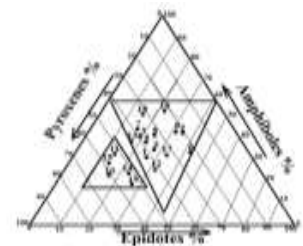

Fig.(4): Triangular representation of amphiboles \& pyroxenes and epidotes relationship in the studied soils.

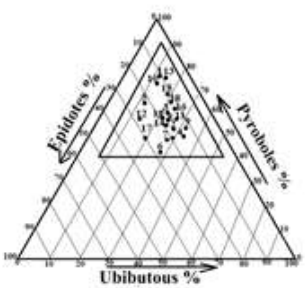

Fig. (6): Triangular representation of pyroboles \& epidotes and ubibutous relationship in the studied soils.

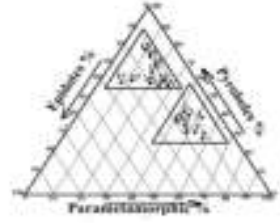

Fig.(5): Triangular representation of pyroboles \& epidotes and parametamorphic relationship in the studied soils.

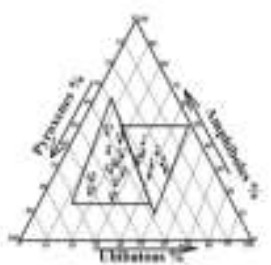

Fig.(7): Triangular representation of amphiboles \& pyroxenes and ubibutous relationship in the studied soils.

\section{References}

Biswas, T. D. and Mukherjee, S. K. (2006) Text Book of Soil Science. Six. rep. Tata McGraw- Hill, Publ. Comp. Ltd., New Delhi, India.

Bowles, J.F.W., Howie, R.A., Vaughan, D.J. and Zussman, J. (2011) Rock-Forming Minerals: Non-Silicates: Oxides, Hydroxides and Sulphides. Geol. Soc. V. 5A, sec. ed., London, U.K.

Cascalho, J., Cota, P., Dawsan, S., Milne, F., and Rocha, A. (2016) Heavy mineral assemblages of the Storegga tsunami deposit. Sedim. Geol., 334, 21-33.

Horvath, B., Opara-Nadi and Beese, O. F. (2005) A simple method for measuring the carbonate content of soil. Soil Sci. Soc. Am. J. 69, 1066-1068.

Jay, A. S. (2015) Forensic chemistry fundamental and applications. Foren. Sc., Mi., S. Un., U.S.A.

John, R.W. Allen, J.,K. and Aaron, A. K. (2015) Heavy minerals in the late Eocene sandstone of Medicine Pole Hills, southwestern North Dakota. Rocky Mountain Geology, Geol. Sci. 50, 1.1., USA.

Karmakar, R.M. (2014) Sand mineralogy of soils of Assam soils developed on different land forms in North Bank Plain Zone of Assam. II. Sand mineralogy. Agropedology, Dep. of S. Sci. Fac. of Agri., Assam, Agri. Uni., Jorhat, (01), 64-69. India. 
Kettler, T.A., Doran, J.W. and Gilbert, T.L (2001) Soil particle size: simplified method for soil particle-size determination to accompany soil-quality analysis, s. sci. soc. Amer. J., 65, 849-852.

Mahaney, W.C., (2002) Atlas of Sand Grain Surface Textures and Applications. Oxford Univ. Press, Oxf., U.K.237.

Mange, M.A. and Maurer, H.F.W. (1992) Heavy Minerals in Color. Chapman \& Hall, London, U.K. 147.

Retsch G.H., (2009) Sieve analysis taking a close look quality. P. 1:52. In. S.B.N. 10, 0-8493-7038-8.

Soil Taxonomy (2014) Keyes Soil Taxonomy. USDA, Washington, D.C.,U.S.A.

Suresh, M., G. and Raja, M. (2014) Heavy mineral distribution and geochemical studies of coastal sediments between Besant Nagar and Marakkanam, Tamil Nadu, India. J. Ra., Res., Appl. Sci., 7 (3), P. 256: 268.

\section{منرالوجيا الرمل كداله لتجانس التربه شمال غرب وادى النطرون}

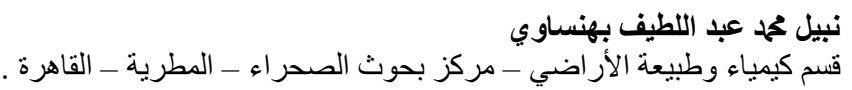

تم إختيار خمس قطاعات أرضيه لتمثل تحت المجموعات التقبيميه

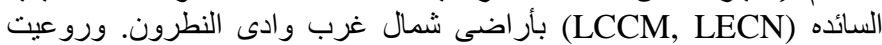

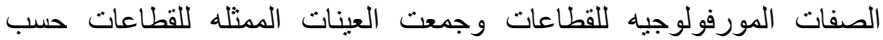

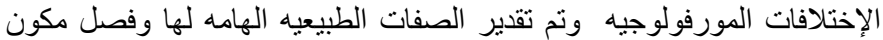

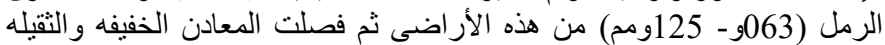

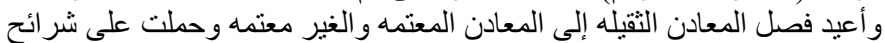

زجاجيه وفحصت بإستخدام الميكروسكوب المستقطب وميكروسكوب المبن الخامات.

وأوضحت النتائج أن المعادن الخفيفه تتميز بسيادة معدن الكوارتز بليه

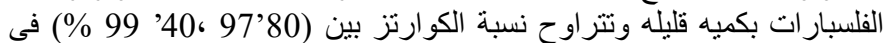

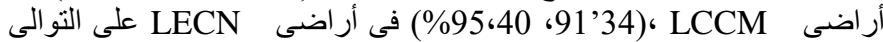

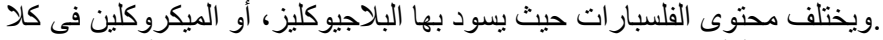

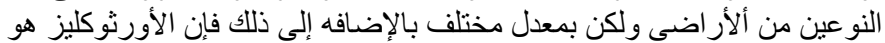

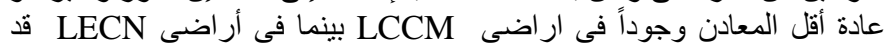

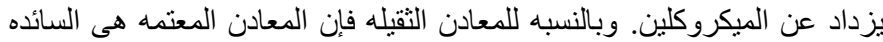

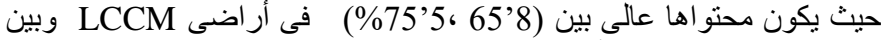

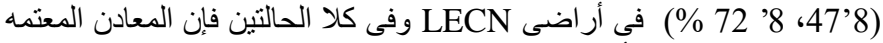

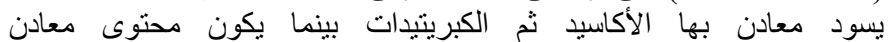

Egypt. J. Soil Sci. 56, No. 4 (2016)

$$
\text { الهيدروكسيدات أقل ما يمكن. }
$$


وبإختصار فإن المعادن فى أر اضى تحت مجموعة LECN تتميز بالسياده

النسبيه لمعادن البيروكسينات (augite-hyperthene-enstatite-diopside) وألأمفيبو لات (tourmaline) ubibutous و (glaucophane-tremolite) وألإبيدوت (zoisite-clinozoisite- epidote ) و المعادن ألأخرى البيوتيت. بينما تتميزتحت مجموعة أراضى LCCM بسيادة معادن ألأمفيبولات

-sillimanite- garnt-staurolite) و الإنفارن (horblende) (kyanite-andalusite

وقد تم عرض التوزيع التكرارى والتوزيع بالعمق لكل المعادن الموجوده

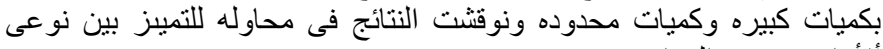
ألأر اضى تحت الديره وكمات اسه. 